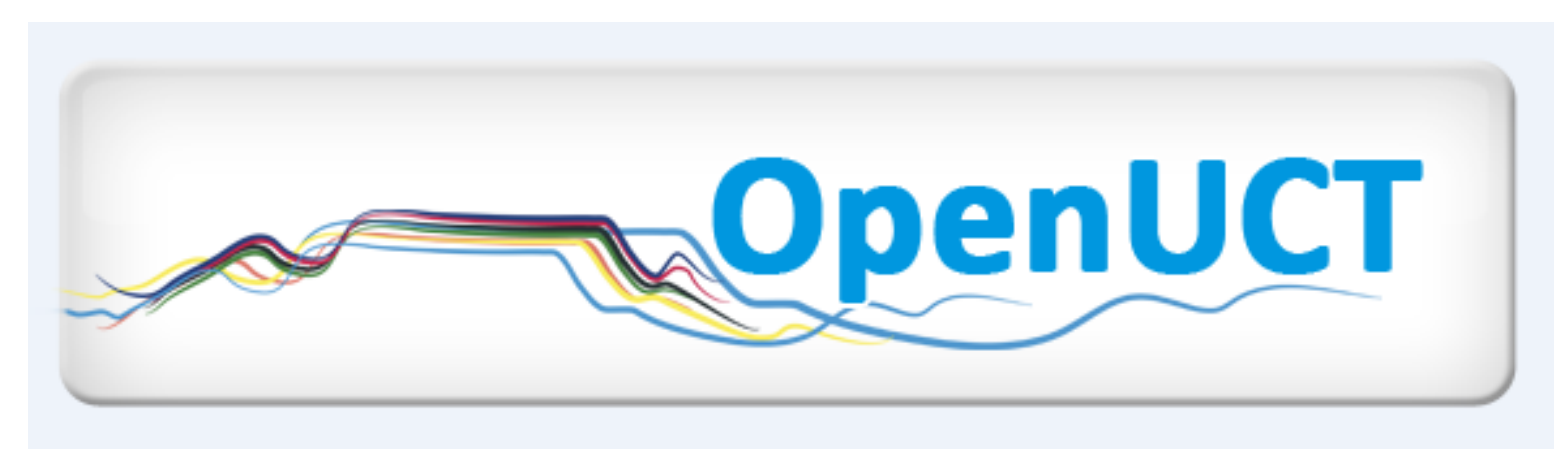

This is the author-approved manuscript version of a journal article published in:

Jawitz, J. 2008. Learning to assess in the academic workplace: case study in the natural sciences. South African Journal of Higher Education. 22(5): 1006-1018.

It is made available under the terms of agreement between the author and the journal, and in accordance with the University of Cape Town's Open Access Policy for the purposes of research, teaching and private study.

http://www.openuct.uct.ac.za/sites/default/files/UCTOpenAccessPolicy.pdf 


\title{
Learning to assess in the academic workplace: Case study in the Natural Sciences
}

\author{
J. Jawitz \\ Higher and Adult Education Studies and Development Unit, Centre for Higher Education \\ Development, University of Cape Town, South Africa. \\ E-mail: jeff.jawitz@uct.ac.za
}

\begin{abstract}
A study into how academics learn to assess student performance affirms the significance of context in understanding learning in the academic workplace. The study involved three case studies in academic departments with significant differences in the teaching, research and professional dimensions of academic life. This article reports on the experiences of new academics in one of the case studies, a department in the Natural Sciences. This case study highlights how relationships between colleagues, opportunities for conversations about assessment practice, and the alignment of assessment practices with the kinds of capital valued in each context are important considerations in understanding the ease, or difficulties, new academics experience in learning to judge student performance. Programmes that aim to help academics develop their assessment practice need to recognise that learning to judge student performance involves developing confidence to create and use opportunities to learn within the academic workplace.
\end{abstract}

\section{INTRODUCTION}

This article arises out of a study at the South African University ${ }_{1}$ (SAU), a historically white research intensive university, into how new academics learn to judge student performance in complex assessment tasks. Three case studies were explored in departments with fundamentally different relationships between teaching, research and the profession representing the academic workplace across significantly different disciplinary contexts. In none of the three cases was there a formal system of support for new academics in learning to assess student work. In this study assessment was regarded as a social practice involving interpretation and academic judgement rather than as a type of measurement (Gipps 1999; Knight 2002; Shay 2003). Assessment practice in higher education involves tacit knowledge that cannot be described because 'the assessor's knowledge exists in the practice of the skill and not in a set of published maxims' (Gonzalez Arnal and Burwood 2003, 383). Learning to assess involves 'participating in relevant social practices, observing, copying, imitating' (Gonzalez Arnal and Burwood 2003, 386). Newcomers to an academic department 
bring with them knowledge gained from previous experiences of assessment. While, in some instances, they may have access to assessment guidelines and criteria in their new workplace, in general, their challenge is to access the tacit knowledge of assessment practice that is embedded within the members of the department.

\section{LEARNING IN THE ACADEMIC WORKPLACE}

Theories of social practice regard learning as the 'inevitable product of everyday thinking and acting, shaped by workplace practices in which individuals participate' (Billett 2001, 19). The structure of work activities and the nature of relationships in the workplace provide opportunities for informal learning experiences (Eraut 2004, 248). In many workplaces, structured pathways of activities exist for newcomers that are 'inherently pedagogical' and provide 'access to the knowledge needed to sustain those practices' (Billett 2004, 119). While each individual's experience will be unique, the opportunities for learning are influenced by the power relations in the workplace.

I have used Bourdieu's theory of practice to analyse the relationship between individual academics and their academic contexts. According to Bourdieu 'a field consists of a set of objective, historical relations between positions anchored in certain forms of power (or capital) ... , a relational configuration ... which it imposes on all the objects and agents which enter in it' (Bourdieu and Wacquant 1992, 16-17).

Each individual in a field carries a habitus which is 'all at once a "craft", a collection of techniques, references, a set of "beliefs"' (Bourdieu 1993, 72-3) formed out of past experiences and socialisation processes. But the habitus is more than just experience; it generates strategies that determine the actions individuals perform in the field 'which can be objectively consistent with the objective interests of their authors without having been expressly designed to that end' (Bourdieu 1993, 76). Bourdieu argues that the habitus of individuals exposed to the same fields and the same 'logic of action' over an extended period of time, gives rise to a 'class habitus' which 'enables practices to be objectively harmonized without any calculations or conscious reference to a norm' and without any 'direct intervention or ... explicit co-ordination' (Bourdieu 1990, 58).

Situated learning theory views knowledge as being distributed amongst the members of a community of practice and as such it can only be understood with the 'interpretive support' provided by participation in the community of practice itself (Lave 1996; Lave and Wenger 1991). Wenger describes a community of practice $(\mathrm{CoP})$ as being constituted by the way people interact with each other and 'tune' their 'relations with each other' and defines membership of a CoP in terms of three aspects: mutual engagement in a joint enterprise, using a shared repertoire of 'routines, words, tools, ways of doing things' (Wenger 1998, 83). In situated learning theory newcomers learn through participation in legitimate activities in a peripheral capacity that does not involve high levels of responsibility (Lave and Wenger 1991). Through this legitimate peripheral participation (LPP) the newcomer's identity settles 
into a trajectory linking past experiences with future possibilities of membership of the CoP (Wenger 1998). In this study the teaching CoP was defined around the joint enterprise of delivering an educational programme, and the research CoP around the production of knowledge through research.

\section{THE CASE STUDY IN NATURAL SCIENCE}

The case studies were chosen because they highlight particular contextual differences in analysing the academic workplace and not as representative of particular disciplinary clusters. In the first case study involving a department in a faculty of Social Science (Jawitz 2007), the experience of new academics was shaped by their interaction with two separate communities of practice. The research CoP focused on high status research activities and postgraduate teaching, and consisted of all senior and some middle-level academics in the department. The undergraduate teaching CoP, responsible for the relatively low status undergraduate teaching activities, included all new and some middle-level academics and large numbers of postgraduate tutors. This separation of the older experienced academic staff from the bulk of the teaching at undergraduate level had significant implications for the way in which new academic staff were inducted into the practice of assessment in the department.

In the second case study the department consisted of sixteen full time academics and an equal number of postdoctoral researchers. The department had experienced substantial change in the previous ten years including a merger of two smaller departments, the emergence of two new interdisciplinary research areas, and a substantial increase in the proportion of female academics. A three-year undergraduate degree was offered with four streams of specialization. This was followed by a oneyear Honours degree which served to select students wishing to do a Masters Degree offered by dissertation only. The department did not offer first year undergraduate courses so there were no large classes.

Interviews were conducted with thirteen of the sixteen academics including all eight female and both black academics in the department. I also drew on data from observations of Honours project presentations, and occasional visits to the tea room. This article draws substantially on the experiences of two new academics, Joe, a black male academic, and Jane, a white female academic, both in their first year of teaching with supporting data from two female academics Claire and Clara who had been teaching for between six and eight years.

A key feature of the department was the dominant role of the Research CoP. Appointment as a lecturer in the department required a Ph.D. and several years of postdoctoral research experience. All academics joined the department as members of the research CoP and taught at both undergraduate and postgraduate levels with no postgraduate student involvement in teaching. A key incentive for all academic staff to teach at the undergraduate level appeared to be the need to attract students into one's sub-discipline as postgraduate students. 
The main aim of the undergraduate and postgraduate programmes was to produce graduates who were skilled scientific researchers to work either in private research laboratories or in university research departments. Given the strong link between teaching and research and the fact that all academics participated in teaching at all levels, the teaching CoP can be conceptualised as being embedded within the research CoP (Figure 1). While there was a valuing of the teaching function, given the role it played in producing researchers and hence in supporting research, there appeared to be an assumption that research and teaching drew on the same experience and skills, the same capital. A newcomer's habitus as researcher was thought to be able to deal with the challenges of teaching. As a result there were no obvious systems of support for developing one's teaching.

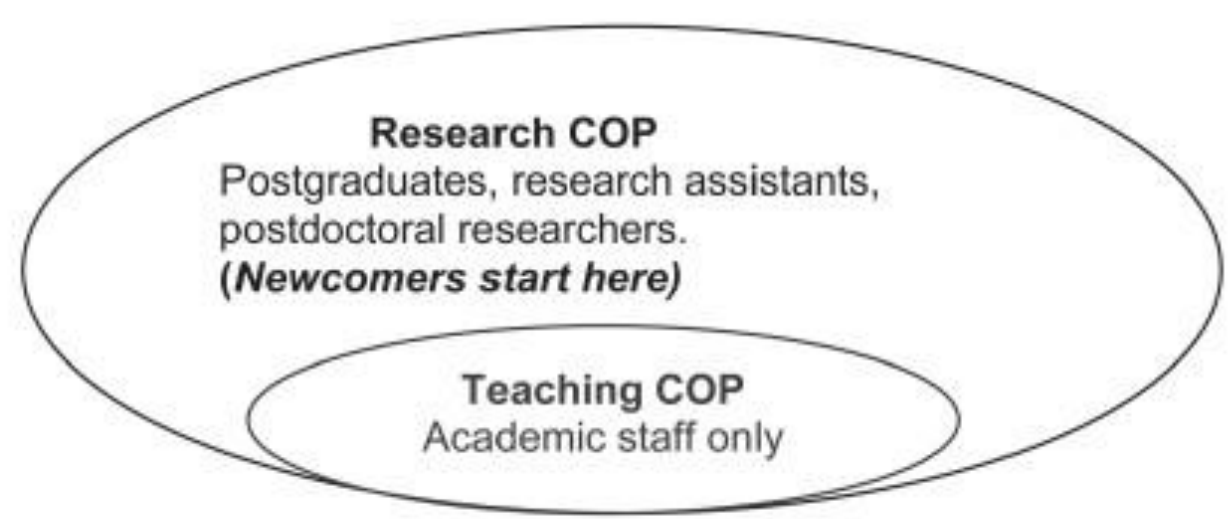

Figure 1: Relationship between CoPs in the department in Natural Science

As one of only two black academics in the department, Joe brought with him cultural capital that differed significantly from that of his white colleagues. His habitus incorporated the experience of being a black student in the department and he displayed an acute awareness of the complexities surrounding his transition from being a black student to being a black academic at SAU. He struggled to define his role as a black academic. He spoke at length about his interaction with the black students in his lab, expressing concern at their view that some of his white colleagues were racist, based on what they perceived to be preferential treatment given to white students in marking and the allocation of scholarships.

Given his own experience as a black student in the department, he could identify with the perception that white academics discriminated against black students. $\mathrm{He}$ recalled how he and his fellow black students had felt it was 'unfair' that after putting 'a lot of effort' into their Honours projects they had been awarded 'less marks than the white students'. He commented on how his perspective had changed since his appointment as an academic. 'Looking back I realize ... it may not have been a race questions it may just have been that our English was bad ... I have realized now in this position that ... there are other pressures on academics which students are unaware of.' [Joe] 
These statements reflect his emerging identity as an academic and the new perspectives that went with it. He admitted that he had only discussed the students' concerns with Jane 'because she's new' and he could 'trust her'. He felt the climate in the department did not encourage the discussion of such issues.

\section{ASSESSMENT PRACTICE}

New academics were required to participate in the complex assessment tasks that formed part of the Honours course, the third year project, and the marking of Masters theses from their first year of appointment (Figure 2). Assessment practice reinforced the alignment between teaching and research. A second year essay had recently been changed into a poster project and a third year essay into a journal club exercise. The output of the third year project was an article suitable for submission to an academic journal. At the Honours level the assessment tasks were spread throughout the year and provided students with an induction into the different genres of communication within the research community.

\begin{tabular}{|l|l|}
\hline \multicolumn{2}{|c|}{ Sequence of complex assessment tasks } \\
\hline \multicolumn{1}{|c|}{$1^{\text {st }}$ Semester } & \multicolumn{1}{|c|}{$2^{\text {nd }}$ semester } \\
\hline $\begin{array}{l}\text { Honours specialist essay } \\
\text { Honours proposal presentation } \\
\text { Honours literature review }\end{array}$ & \\
\hline & $3^{\text {rd }}$ yr project \\
& $\begin{array}{l}\text { Honours journal paper } \\
\text { Honours oral presentation } \\
\text { Masters Thesis }\end{array}$ \\
\hline
\end{tabular}

Figure 2: Complex assessment tasks in first year of appointment

For each of these complex assessment tasks markers had to write a report explaining their mark but it was unclear how they were used. Some interviewees said the reports were for the external examiners, while others said they were to help resolve differences between markers. No feedback was given to the authors of the report.

Departmental policy discouraged markers who were marking the same scripts from talking to each other about the script or the student they were marking as assessment was regarded as a private affair, requiring academics to reach independent judgements. This policy appeared to try and align assessment practice with the scientific method and views on the need for objectivity that dominate disciplines in the Natural Sciences (Handal, Lauvas and Lycke 1990). Jane felt that the policy helped to ensure a degree of fairness and wanted it to be implemented consistently across the department. However, Joe was ambivalent about the policy as he felt it 
denied him access to information that might help him in his judgements. According to Clara the existence of the policy suggested that academics themselves were being judged through their marking.

One gets a sense you're not meant to be discussing marks beforehand. It's almost your exam of how well you mark. [Clara]

Joe struggled with the notion of being 'objective'. He commented on how 'very tough' and 'very subjective' the marking of third year projects was especially when it involved marking one's own students.

When it comes to marking your own student you're always subjective, you subconsciously ... try to be objective. Right? But ... you become subjective by the nature of knowing the person. [Joe]

Jane appeared more confident than Joe about approaching colleagues to discuss marking. She mentioned that she had 'talked a lot about the marks' with some colleagues who she had co-supervised third year project with. However she expressed frustration by the fact that Claire had been unable to discuss assessment criteria with her when she had approached her to explain how she marked the Honours literature reviews.

I don't think they're really very accessible so I think because Joe and I feel a bit lost, I think it's natural to gravitate together. [Jane]

She and Joe had discussed assessment criteria.

It was the first time we'd been involved in the Honours marking thing and so we talked ... about ... how you mark an essay and a literature review ... Joe had been on the internet and he'd found various articles about how to mark... . We discussed how we would approach it and then we went independently and we didn't speak again. [Jane]

Jane was appointed to serve on a newly established review panel to moderate the marks awarded for third year projects and reported that the experience gave her the opportunity to 'see what other people value' and 'affirmed' what she was 'valuing'.

Some of the senior interviewees had attended a three day teaching workshop about ten years previously and referred to the influence of that workshop on their assessment practice. Both Jane and Joe had attended workshops on assessment as part of a support programme for new academics at SAU.

[It] gave me some tools that I could use... . As a new academic I was totally lost and it kind of gave me some base which I could work from. [Joe] 


\section{RESOLVING DIFFERENCE}

It was widely acknowledged within the department that some academics were 'strict' and others were 'lenient' in their marking.

We've got a lot of rules in place to allow for this difficult kind of assessment, particularly at Honours level because we've had a lot of fights in the past. [Claire]

As in the first case study (Jawitz 2007), double marking was used to enhance the reliability in the assessment of complex assessment tasks, based on the assumption that two competent markers should 'find the right mark'. Where the difference in marks between the two markers was less than 10 per cent, the average was taken as the final mark. When it was greater than 10 per cent, the script was sent to a third marker and an average taken across the larger set of three.

The view that averaging marks across markers was an acceptable means of arriving at an appropriate result for a student's work was widely held within the department. A senior member of the department regarded it as a 'robust' way of 'reflecting what the student is actually doing' and another felt that by taking the average across three markers one was 'probably getting into the right zone in terms of where the student is'. This arithmetic solution to variation in assessment judgements served to further align the assessment process with experimental procedures in the Natural Sciences and enhanced the impression of objectivity and further illustrates how teaching practice was 'influenced by the dominating rationality of the discipline' (Handal, Lauvas and Lycke 1990).

While this mechanism of dealing with difference avoided the need for discussion and negotiation, it made it difficult for new academics to understand the issues underlying the difference in marks. A critical incident involving Joe's first experience of assessing the Honours literature review occurred just prior to my first interview with him. He had marked four scripts and passed them all, including that of a black student he had supervised. While the marks he had given the students he had not supervised had been 'very similar' to their final marks, he had been 'shocked' to see that his own student had failed and had immediately gone to see what the other markers had awarded him.

The second marker gave him $40 \%$, I gave him $62 \%$ and the third marker gave him ... $46 \%$ or something. [Joe]

The final mark of 49 per cent had been calculated by taking the average, without discussion with him or the other markers. This experience had shaken his confidence as he regarded it as an indirect criticism of the way he had marked the student he had supervised. He had felt confident about his assessment as he had used a set of assessment criteria developed in the discussion with Jane described above. He wished to get feedback on how to improve his assessment practice but felt fearful of approaching the other markers. He never did so. 
How would she perceive me coming to her ... as a new academic? ... Would she take it to mean: 'You know you're actually criticizing my assessment and you're criticizing, you know, me'? [Joe]

\section{NO PERIPHERALITY}

There was no evidence of opportunities to learn about assessment through legitimate peripheral participation. The emphasis on achieving objectivity through independent and 'unbiased' judgement meant that each academic was expected to reach his or her judgement alone and with very little discussion. New academics who arrived in the department as members of the research CoP were expected to perform at the required level in the teaching CoP. Their concerns for how they might be viewed by their colleagues influence their judgement of a student's performance.

Rob, a colleague with about 6 years teaching experience, highlighted the relationship between judging student performance and one's reputation. He commented that one needed to be careful of 'attracting the wrong kind of attention' by not marking too high and that it was safer to mark in the 'middle zone'. Jane admitted to feeling 'very nervous' when marking a student she had supervised. She felt that she had been 'more strict' with her own student because she 'didn't want to appear to be favouring him' more than the other two students she was marking. There had been an occasion when she had felt anxious marking an Honours project because she knew that she marked 'differently to certain people' and knew that she would 'be giving their student a lower mark than they would be giving them'. She knew 'there would be a problem'.

As all academics arrived in a department with a Ph.D. they were called upon to mark Masters theses. Jane found it 'scary to know that you were deciding someone's degree basically based on that thesis' and had approached Claire and some colleagues outside of SAU for advice. Claire felt that the lack of guidelines for marking Masters theses was a problem and said she had probably been 'very harsh' the first time she marked a Masters thesis. Joe commented that he was aware that there were often large differences between markers at the Masters level where 'one external will give a distinction ... the other external totally opposite'. Claire gave a recent example.

One external said: "Outstanding", one external said: "Great" ... and then the internal said: "Absolutely terrible"... . The internal person was new and so ... I think the decision was made that the internal was actually being too harsh. [Claire]

Experiences like this had made her 'quite cynical about the whole marking thing'. She felt that if this degree of disagreement was possible at Masters level, there was little chance of getting 'people to agree on a standard' for marking student work in general. For Clara the process of marking Masters theses was guided by the "golden standard' of the research journal article. 


\section{DEVELOPING CONFIDENCE}

Despite the lack of opportunities for legitimate peripheral participation and the limited opportunities to talk, a system of judging student performance had evolved within the department, in which the majority of academics and external examiners appeared to have confidence.

Within the first few months of starting work at SAU Jane had been required to assess a third year project and an Honours paper. She spoke of the importance of using criteria to ensure 'transparency' and clearly described the ones she used in marking. She mentioned two occasions when her confidence in her marking had been boosted as a result of discussions with colleagues. On one occasion she had approached a senior colleague, the second marker on a third year project, to discuss why their marks had differed by 5 per cent. She had explained why she had given the extra 5 per cent and the colleague had agreed with her. On a second occasion she had discussed her marking with the Honours convenor who felt that she was 'being very generous' with her marks on a course that they shared. After she had explained how she marked, he acknowledged he had been 'looking for a different answer'. However she remained uncertain about the standard in the department that she was supposed to work towards in her marking.

Because you're applying your standards to the project ... you may be looking for very different qualities... . That's always my worry is that I have very different standards ... to what is being looked for. [Jane]

When interviewed again six months later, the additional experience of having supervised and marked more third year projects, and having her own Honours student, had strengthened her confidence in her marking.

Having exposure to more students, and to more projects, helped me gauge better how the projects were looking in the whole class. [Jane]

Although she felt more comfortable with her marking, she was still unsure whether she was doing what the department expected of her.

There are some things that I judge based on whether they are scientifically valid and I don't know whether all people do... . I'm marking true to myself but I don't know whether I'm marking true to how the department marks. [Jane]

Despite this, she found that her marks usually ended up being 'very similar' to that of the second marker, leading her to comment that even though one may be looking for different things 'it all evens out in the end'. This notion of the inevitable convergence of marks, despite the possible use of very different assessment criteria, emerged in several places in this study and seemed to reinforce a sense of confidence in the system. 
Joe reflected on how 'tough' marking had been during his first year as an academic, and described the development of his individual assessment 'style' as a 'work in progress'.

Initially ... you have this impression that everybody marks the same ... everybody gives $60 \%$. But I then realized actually that even amongst the senior academics there's big differences in marks... . Becoming comfortable with your own marking assessment is also something that I did realize would take time ... I'm trying to find my own individual style which I'm happy with. [Joe]

Joe felt strongly in the need to use criteria, as they not only provided a framework for marking but were also important in helping students to do the task and to understand the feedback they got.

You have to have a set of criteria ... to judge the essay, allowing the student to use that criteria to formulate the essay ... then whatever mark they get they know why they're getting that mark. [Joe]

He expressed frustration at the fact that he did not know what assessment criteria other markers applied.

Is he using the criteria of [his institution]? ... Is he making his criteria plain to us?... I would like to know how externals judge... . He obviously marked the projects according to his ... criteria. [Joe]

The data in this case strongly suggests that collectively the members of the department did not see the need for making assessment criteria explicit or for reaching agreement on how to judge student performance in complex assessment tasks. While the path appeared to differ for each academic, the development of the individual habitus appeared to proceed from a search for structured support, to a realization that there was none and the development of confidence that one knows what counts and that 'things will all even out' either serendipitously, or with the help of an arithmetic consensus-reaching mechanism such as taking the average.

\section{DISCUSSION}

An analysis of the data in this case study revealed several key features related to the process of learning to judge student performance.

There was no evidence of legitimate peripheral participation in assessment practice within the department. The process of assessment for new academics involved having to make judgements of student performance in situations that involved potential disagreement and could reflect poorly on themselves as academics.

In the first year as an academic, newcomers were faced with having to assess multiple complex tasks in quick succession (Figure 2). The cycle of assessment tasks was repeated each year providing the opportunity to learn by reflecting on 
the previous years' experiences. However, given the lack of feedback or discussion within the department, each individual academic was left to draw on their own resources in this reflective process.

The development of the academic habitus in respect of assessment practice appeared to proceed with little interaction with other members of the community of practice. Double marking took place in an environment of little discussion and feedback, and appeared to serve primarily as the basis for an arithmetic approach to determining a 'reliable' mark. Joe's experience illustrated how such an approach did not assist academics in understanding how to judge student performance. If anything, it encouraged strategies such as marking within a 'safe' zone.

One way of explaining the process of learning to assess in this context is that it involved adopting an individualistic approach within certain limits, knowing that there were mechanisms for arriving at a final mark irrespective of what mark you gave. Newcomers felt uncomfortable with this process, but they soon became immune to differences with their colleagues over marks, and left the course convenor to use the administrative processes, arithmetic consensus management and external examiners to arrive at the final marks. The development of confidence could be said to have been based on a realization that there was no need to reach agreement, as structures were in place to ensure a mark would be awarded anyway. Newcomers learned to stop searching for rules and criteria for marking. They realized that there was no need for agreement on criteria because no one applied them consistently, and they did not provide the basis for discussion with colleagues. The habitus of the new academic resulted in the adoption of the practices that were 'harmonized' with that of the community of practice 'without any calculations or conscious reference to a norm' and without any 'direct intervention or ... explicit co-ordination' (Bourdieu $1990,58)$.

\section{CONCLUSION}

A substantial finding of this case study highlights the importance of context in understanding how academics learn assessment practice in the academic workplace. The particular relationship between the research and teaching communities of practice, the disciplinary factors shaping assessment practice and the alignment of key complex assessment tasks with research, are important considerations in understanding the ease, or difficulty, new academics experience in learning to judge student performance.

The lack of opportunities for legitimate peripheral participation was a central feature of this case study, similar to that described in a study by Viskovic in which 'people had had to move very quickly into full participation in work - little time was spent on the periphery, as their inbound trajectories quickly immersed them in the full demands of practice' (Viskovic 2005, 401). 
Furthermore, the lack of opportunities for conversations and feedback on assessment meant that new academics needed to learn to make judgements about student performance on their own.

Signs of growing confidence in one's assessment practice signalled the development of an academic habitus that 'fitted' into the field. The basis of the confidence that emerged in this case study can be interpreted as reflecting an increasing understanding of how to 'play the game' and how to make judgments that would not require justification or would not lead to confrontation with one's colleagues.

Strategies adopted by academic staff development practitioners need to be sensitive to the complex and context dependent nature of the process of learning to judge student performance. They need to understand the sequence of assessment activities that form part of the learning pathway for new academics and develop ways of supporting the engagement of new academics in the assessment processes along this pathway.

Secondly, while acknowledging the effect of power relations within departmental communities, the learning of new academics could be strengthened by increasing the frequency of conversations about assessment practice. One would also need to find ways to promote the understanding and use of key concepts in assessment in the conversations within departmental communities so that academics develop a common language with which to discuss assessment practice and are able to draw on conversations external to the department such as those in external training opportunities and assessment documentation from other educational institutions.

Participation by members of a department in academic staff development activities outside of the department needs to be supported by interventions that will enable such 'external' learning to be incorporated into the conversations and activities within the departmental communities of practice. The emphasis needs to be on creating learning communities rather than simply providing opportunities for individuals to learn. This requires a focus on supporting relationships within communities of practice that encourage the sharing of understandings and negotiations around the distributed knowledge of assessment. Working in a department in this way would ensure that all academics are exposed to opportunities to develop their practice, rather than just the newcomers or those who choose to attend external staff development opportunities.

\section{NOTE}

1. A fictitious name chosen to protect the identity of the institution concerned. The names of all persons and departments have also been changed.

\section{REFERENCES}

Billett, S. 2001. Learning throughout working life: Interdependencies at work. Studies in Continuing Education 2 (1): 19-35.

—. 2004. Learning through work: Workplace participatory practices. In Workplace learning in context, eds. H. Rainbird, A. Fuller and A. Munro, 109-125. London: Routledge. 
Bourdieu, P. 1990. The logic of practice. Stanford, California: Stanford University Press. 1993. Sociology in question. London: Sage Publications.

Bourdieu, P. and L. J. D. Wacquant. 1992. An invitation to reflexive sociology. The University of Chicago Press.

Eraut, M. 2004. Informal learning in the workplace. Studies in Continuing Education 26 (2): 247-273.

Gipps, C. 1999. Socio-cultural aspects of assessment. Review of Research in Education 24:355-392.

Gonzalez Arnal, S. and S. Burwood. 2003. Tacit knowledge and public accounts. Journal of Philosophy of Education 37(3).

Handal, G., P. Lauvas and K. Lycke. 1990. The concept of rationality in academic science teaching. European Journal of Education 25 (3): 319-332.

Jawitz, J. 2007. New academics negotiating communities of practice: Learning to swim with the big fish. Teaching in Higher Education 12 (2): 185-197.

Knight, P. T. 2002. Being a teaching in higher education. Buckingham: The Society for Research into Higher Education \& Open University Press.

Lave, J. 1996. Teaching, as learning, in practice. Mind, Culture and Activity 3 (3): 149-164.

Lave, J. and E. Wenger. 1991. Situated learning: Legitimate peripheral participation. Cambridge: Cambridge University Press.

Shay, S. 2003. The assessment of undergraduate final year projects: A study of academic professional judgment. Unpublished doctoral dissertation, University of Cape Town, Department of Education.

Viskovic, A. R. 2005. 'Community of practice' as a framework for supporting tertiary teachers' informal workplace learning. Journal of Vocational Education and Training 57 (3): 389-410.

Wenger, E. 1998. Communities of practice learning, meaning, and identity. Cambridge: Cambridge University Press. 